\title{
Evolutionary Trends of the Genus Ancyrogondolella (Conodonta) and Related Taxa in the Norian (Late Triassic)
}

\author{
Viktor Karádi (ii)* \\ Department of Palaeontology, Eötvös Loránd University, Budapest 1117, Hungary \\ (ii) Viktor Karádi: https://orcid.org/0000-0002-5923-2944
}

\begin{abstract}
The Norian represents the longest stage of the Triassic, nevertheless, its precise subdivision is an unresolved matter. Conodonts might be useful in the establishment of an accurate biozonation to avoid common scientific misinterpretations. Understanding the Norian evolutionary trends and morphological changes of the Ancyrogondolella lineage (genus Ancyrogondolella and descendant genera Epigondolella, Orchardella and Mockina) is of key importance in this issue. The forward shifting of the pit and the posterior prolongation of the keel and the carina characterize the main trend that corresponds to the faunal turnover around the Lacian-Alaunian transition. A gradual decrease in overall element width and length can be observed from that time on, which couples with a decrease in the length of the free blade and an increase in the height of the anterior platform denticles. The presence of secondary carinae is characteristic for the mid-Lacian 1 to Alaunian 1, but their development shows no trends and has no taxonomic value. Adult specimens of the Lacian generally have an arched lower profile, whereas in the Alaunian and Sevatian the lower profile is dominantly stepped or straight. The thorough documentation of the Tethyan assemblages is needed for any detailed taxonomic and paleobiogeographic comparisons with other regions.
\end{abstract}

KEY WORDS: conodonts, evolution, Ancyrogondolella, Late Triassic, Norian, Lacian, Alaunian, Sevatian.

\section{INTRODUCTION}

The Norian, with its approximately 20 Ma duration (Kent et al., 2017; Maron et al., 2015), is the longest stage of the Triassic by representing more than $1 / 3$ of the whole system. It is divided into three substages, the Lacian (Lower Norian), the Alaunian (Middle Norian), and the Sevatian (Upper Norian), respectively. However, research activity has focused mainly on the Carnian-Norian and Norian-Rhaetian boundary intervals, driven by the intention to establish the Global Stratotype Section and Points (GSSPs), and evidently less emphasis has been placed on other parts of the Norian that fall out of the ranges of both stage boundary intervals. Comparison with the short time spans of the stages or, even more, the widely used substages of the Lower and Middle Triassic may give the false impression that the Norian was a more stable time interval with less biotic or physical events. This is clearly not the case, however the fine subdivision of the Norian is still pending.

Most alternative stratigraphic methods require calibration to well-defined biostratigraphy or to radiometric ages (which, in fact, are also adjusted to fossils and/or events). Even though the development of radiometric dating provides more and more accurate age data, absolute ages remain scarce since very few

*Corresponding author: kavik.geo@gmail.com; karadi.viktor@ttk.elte.hu

(C) The Author 2021. This article is published with open access at Springerlink.com

Manuscript received October 8, 2020.

Manuscript accepted November 27, 2020.
Norian formations are suitable for such analyses. This fact emphasizes the importance of precise biostratigraphic dating, the necessity of which is also confirmed by the problems around Late Triassic scaling. The long Carnian-short Rhaetian versus short Carnian-long Rhaetian issue (Ogg, 2012), which has divided researchers for years, was generated by cyclostratigraphic calculations and magnetostratigraphic correlations without having properly established (integrated) biostratigraphic control. Further confusion arose with the need to introduce Misikella posthernsteini sensu lato for certain morphotypes of the Steinbergkogel fauna (Kent et al., 2017; Maron et al., 2015) due to contrasting taxonomical interpretations of the conodont species that is widely used to mark the base of the Rhaetian. If the situation was not chaotic enough, a third option has been recently published by Galbrun et al. (2020), suggesting an "intermediate" Rhaetian of 6.69 Ma duration, based on cyclostratigraphic analysis of four Austrian successions. However, the biostratigraphic background used for the correlation of the overlapping sections is highly questionable, and consequently the estimations are debatable, too. Data provided by two independent studies from Peru (Wotzlaw et al., 2014) and from the Pignola-Abriola Section in Italy (Maron et al., 2015) turned out to support a short duration for the Rhaetian by the placement of its lower boundary at 205.5 Ma. Interestingly, this did not result in the fulfillment of the long Carnian option as expected previously, but rather in a long Norian (Kent et al., 2017) being coherent with wellcalibrated zircon-based ages from the late Carnian $(\sim 231 \mathrm{Ma}$; Furin et al., 2006), the late Lacian ( 225 Ma; Gehrels et al., 1987) and the Lacian-Alaunian boundary interval ( $224 \mathrm{Ma}$; Diakow et al., 2012, 2011). 
Biostratigraphy of Upper Triassic marine successions is generally based on ammonoids and conodonts, to some extent also on bivalves. Macrofossils are unfortunately quite rare in many Norian sections, especially from the upper Alaunian, which calls for the establishment of a high resolution conodont biostratigraphy. The pioneer works of Orchard (1994, 1991a, b, 1983) on the rich faunas of the Americas have led to remarkable results in the development of the Norian conodont zonation of the eastern Pacific. Much less data is available from the Tethyan Realm, partly due to natural causes (Karádi, 2018), and partly because several studies present age data that are based rather on the general characteristics of the conodont faunas than comprehensive determination of the taxa. Species names that can cover a large variety of forms (e.g., Epigondolella abneptis, Epigondolella postera, Epigondolella bidentata) are listed in these cases to confirm the age. If this oversimplified taxonomy couples with the lack of illustration, the published results can hardly be challenged and used by other researchers for future studies.

Gathering all available knowledge, Rigo et al. (2018) presented a new Upper Triassic conodont zonation for the Tethyan Realm, being aware of the fact that the Norian part has yet to be refined with the accumulation of further data. However, the revision has to be preceded by thorough taxonomic and phylogenetic investigations, because recent research revealed the uncertainties of conodont systematics even on the generic level (Karádi, 2018; Orchard, 2018). This study aims to summarize the Norian evolutionary trends of the genus Ancyrogondolella and related taxa with discussion on taxonomic problems and differences between western Tethyan and eastern Pacific faunas. The research is based mainly on the materials from Hungary (Karádi, 2018; Karádi et al., 2016, 2013) and Slovenia (Karádi et al., 2021, 2020, 2019) and the evaluation of the literatures and numerous illustrations of Orchard (2018, 2006, 1994, 1991a, b, 1983) and Mazza et al. (2012a).

\section{NORIAN EVOLUTIONARY TRENDS}

The evolution of the Ancyrogondolella lineage in the Norian is characterized by a main trend accompanied by several minor trends. The main trend can be defined by the collective change in three morphological characters (Fig. 1): (1) the forward shifting of the pit from a central position to the anterior half of the platform; (2) the posterior prolongation of the keel behind the pit; (3) the development of additional denticles in the posterior carina behind the cusp. This is the recurrence of the same trend that was documented in the late Carnian (Tuvalian) Paragondolella noahMetapolygnathus praecommunisti-Metapolygnathus communisti lineage by Mazza et al. (2011). The conodont species $P$. noah has the pit in a sub-terminal position with respect both to the posterior platform margin and to the keel end. By this, the keel does not show posterior prolongation and the cusp is terminally located. The pit in Me. praecommunisti is forward shifted towards the platform midlength, which results in a posteriorly prolonged keel and the appearance of two to three carinal nodes following the cusp. The descendant Me. communisti has a pit located below the anterior half of the platform and thus, the posterior prolongation of the keel is more pronounced. Nodes of its posterior carina reach the number of four.

The above described transition happened within the Tuval- ian, whereas the realization of the same evolutionary steps in the Ancyrogondolella lineage took more time. The trend initiated in the late Tuvalian with genus Carnepigondolella evolving into genus Ancyrogondolella, as suggested by Mazza et al. (2012b) based on numerical cladistics analyses. The forward shifting of the pit from a sub-terminal to a central position and the appearance of a carinal denticle behind the cusp can be seen for example in the Carnepigondolella pseudodiebeli-Carnepigondolella orchardi-Ancyrogondolella miettoi-Ancyrogondolella quadrata lineage. Contrary to the evolution from Paragondolella to Metapolygnathus, in this trend the keel end became strongly bifurcated, and this bifurcation reached the pit, so the keel cannot be considered as posteriorly prolonged. Most of the Lacian was characterized by a steady phase; the morphological changes continued only in the transitional interval between the Lacian and the Alaunian. The forward shifting of the pit below the anterior half of the platform together with the loss of keel bifurcation (Orchard, $2018,1983)$ led to the posterior prolongation of the keel. In connection with this change, the number of denticles in the posterior carina grew to two or more, regardless of whether the carina reached to the posterior margin of the platform or not. This development resulted in the appearance of the genera Orchardella, Epigondolella and Mockina. As proposed by Orchard (2018), possible lineages of this trend are: (1) Ancyrogondolella diakowiAncyrogondolella transformis-Orchardella? n. sp. A-Orchardella multidentata; (2) Ancyrogondolella inequalis-Ancyrogondolella? praespiculata-Epigondolella spiculata; (3) Ancyrogondolella spp.-Mockina ex. gr. matthewi via neoteny. The gradual forward shifting of the pit and addition of further carinal denticles can be observed throughout the rest of the Alaunian and the Sevatian. However, examples of evolutionary lineages could hardly be listed at this stage, due to the poor knowledge on the Alaunian faunas.

Besides the main trend, evident morphological changes occurred in the shape of the anterior platform denticles and in the length of the free blade. The Lacian taxa have moderately high, often elongated, ridge-like denticles that developed from the nodes of late Tuvalian species (Mazza et al., 2012b; Orchard, 1991a). In the Alaunian the anterior denticles of the platform continued to increase in height, became sharper and more conical, and these denticles are often backward inclined in late Alaunian and Sevatian conodonts (Fig. 2; see also pl. 3 of Orchard, 1991a). A gradual decrease in the length of the free blade, or from the opposite view, an increase in platform length can be seen in the majority of the taxa during the Norian. The free blade of Lacian taxa is mainly between $1 / 2$ to $1 / 3$, but closer to $1 / 3$ unit length (Fig. 2). This rate varies most in A. rigoi, A. uniformis and $A$. triangularis. Conodonts from the Lacian-Alaunian transitional interval and the early Alaunian generally bear a free blade of $\sim 1 / 3$ unit length. Mockina medionorica seems to be an exception with its long free blade that is nearly $1 / 2$ unit length. From the higher part of the Alaunian and in the early Sevatian, a further reduction characterizes the free blade, the length of which falls between $1 / 3$ to $1 / 4$ unit length, but it is still closer to $1 / 3$ unit length. It is " $O r$ chardella" mosheri morphotype B of the Sevatian that has a free blade reaching close to $1 / 4$ unit length. This evolutionary trend does not seem to apply to Mo. postera and Mo. bidentata; it needs to be noted though that these are paedomorphic species. 


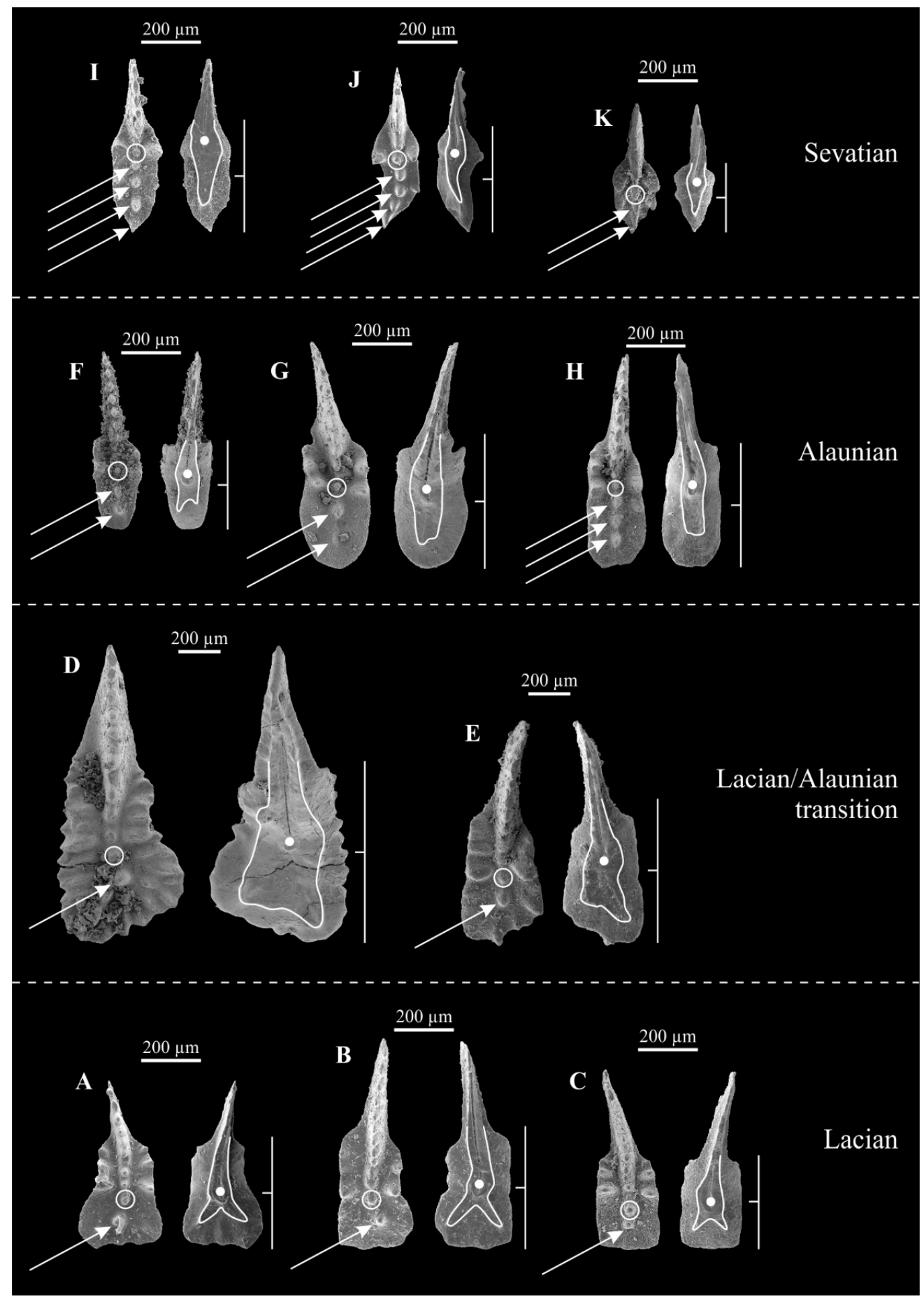

Figure 1. Main trend in the evolution of the Ancyrogondolella lineage during the Norian. White arrows point to the denticles of the posterior carina developed behind the cusp (open circle). Pit position (solid circle) is shown relative to the middle of the platform marked by the white bars on the right of the specimens. Posterior prolongation of the keel with respect to the position of the pit is reflected by the contour of the keel edge. See text for details. Upper and lower views are provided for all specimens. Scale bar=200 $\mu$ m. A. Ancyrogondolella rigoi; B. A. vialovi; C. A. quadrata; D-E. Ancyrogondolella? transitia; F. Mockina medionorica; G-H. M. ex. gr. matthewi; I-J. "Orchardella" mosheri morphotype B; K. M. englandi. Specimens A, D-I from the Buda Hills (Hungary), specimens B, C, J, K from the Csővár area (Hungary).

\section{DISCUSSION}

\subsection{Changes in the Lower Profile}

Rather than following any trends, the lower profiles of conodont elements show characteristic morphologies in certain intervals of the Norian. The change between each state seems to be abrupt instead of transitional. The lower margin of Lacian ancyrogondolellids (and also of Metapolygnathus mazzai) is, in most cases, slightly arched with the posterior platform bending downwards behind the pit (Fig. 3). This applies for the majority of adult specimens, whereas the lower profiles of juvenile and subadult specimens are still underdeveloped having a straight, stepped or upturned appearance. The latter morphologies are 


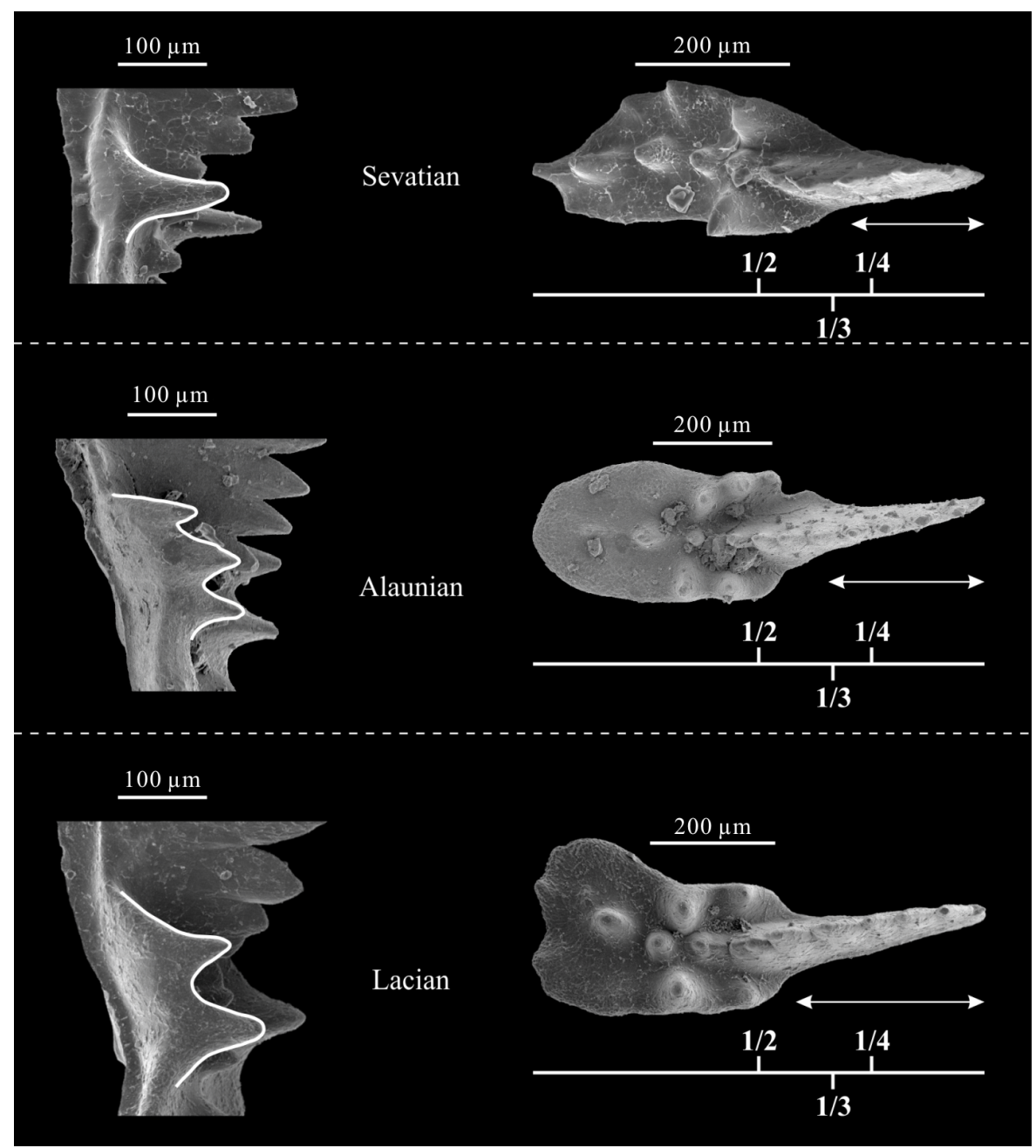

Figure 2. Modifications in the shape of the denticles of the anterior platform and in the length of the free blade in representatives of the Ancyrogondolella lineage during the Norian. Left side, anterior platform denticles are marked by white contour. Scale bar=100 $\mu$ m; specimens are on the same scale. Right side. length of the free blade (double sided arrow) in comparison with the entire element length (bars showing 1/2, 1/3 and 1/4 unit length). Scale bar=200 $\mu$; specimens are not on the same scale. See text for details. The Lacian specimen (Ancyrogondolella ex. gr. rigoi) and the Alaunian specimen (Mockina matthewi) from the Buda Hills (Hungary), the Sevatian specimen (“Orchardella” mosheri morphotype B) from the Csővár area (Hungary).

very rare in adults of Lacian age, but become dominant in the Lacian-Alaunian transition also among fully grown specimens. The stepped lower profile is defined by a pronounced step right below the denticles of the anterior platform margins (Fig. 3). In front of this step and behind it, the lower margin is generally straight. Upturned lower profile is quite rare among adult conodonts even in the Alaunian, but the perfect example for this morphology is the holotype of Epigondolella spiculata (pl. 3, fig. 15 in Orchard, 1991b). Sevatian descendants of the Ancyrogondolella lineage have a nearly straight lower profile with no or only a very gentle step below the denticles of the anterior platform margins (Fig. 3). This feature indicates that adult conodonts from the Alaunian retain neotenic characters of the lower margins. Neoteny was mentioned also by Orchard (2018), who emphasized that the low number of denticles on the anterior platform margins in the genus Mockina might be a typical example of this phenomenon.

Guenser et al. (2019) came to a different conclusion when studying upper Tuvalian and Lacian conodont species by geometric morphometric analyses. They stated that the Carnian an- cestors bear a downward bending lower margin, whereas their (Lower) Norian descendants have a more upward bending lower profile (p. 449 and fig. 5 in Guenser et al., 2019). This statement seems to be inconsistent with the observation made in the present study, which claims that the lower margin of Lacian ancyrogondolellids bends downward. This seeming contradiction results only from a difference in the investigative strategies. Guenser et al. (2019) consistently analyzed the lower margin of the conodont elements between the pit and the anteriormost part of the blade. Consequently, a longer portion of the lower margin was involved in the analysis if the pit was terminally or sub-terminally located (i.e., in many Carnian species). If the pit was shifted to a central position (such as in Lacian Ancyrogondolella), the analysis included only a shorter interval of the lower profile relative to the whole length of the elements. However, if the lower margin along the entire element length is considered, also the Lacian descendants show an arched profile with a downward bending posterior part likewise their Tuvalian ancestors. In fact, a big change in the profile of the entire lower margin did not occur before the Lacian-Alaunian transition. 


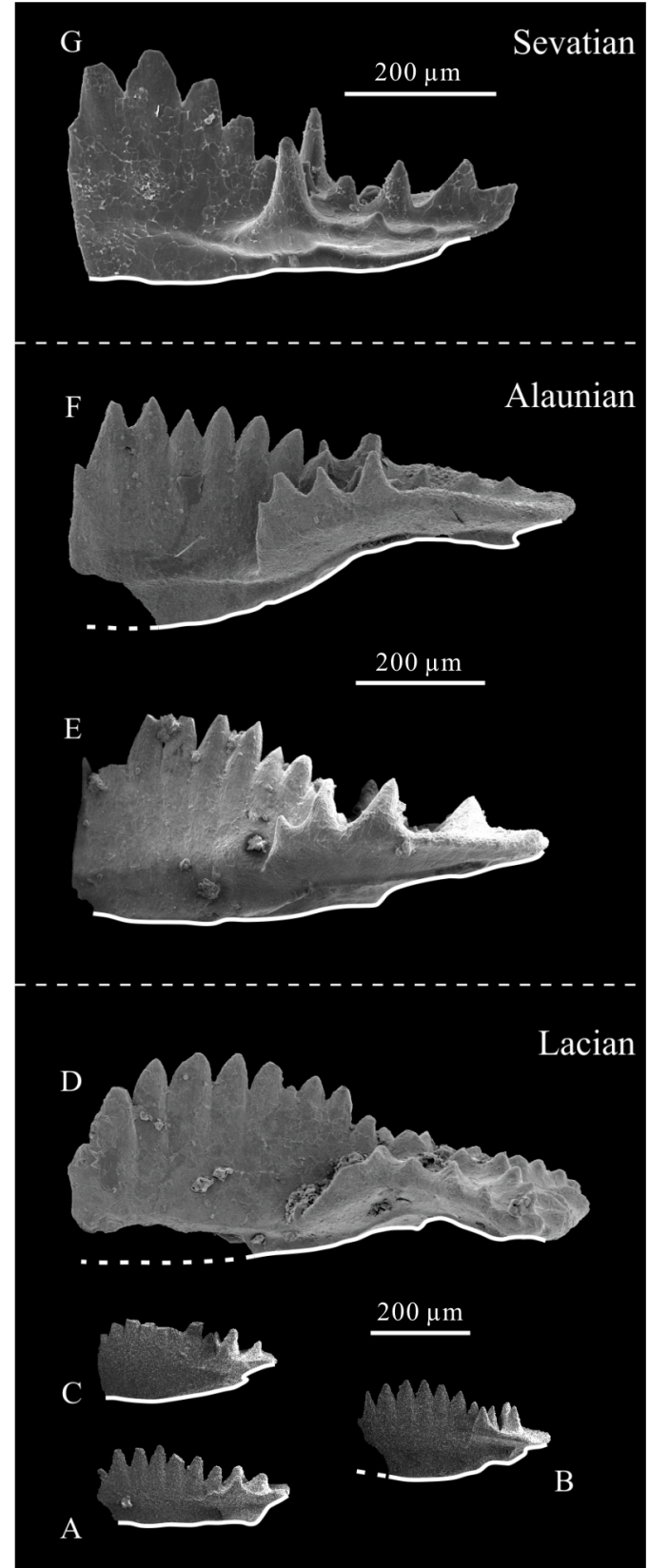

Figure 3. Different lower profiles (white contour) of Norian conodonts of the Ancyrogondolella lineage. Juveniles have straight (A), stepped (B) or upturned (C) lower margin, whereas adults have arched profile (D) in the Lacian. Adult specimens of Alaunian age bear upturned (E) or stepped (F) lower margin, and adults of the Sevatian have quasi-straight profile. See text for details. Scale bar: $200 \mu \mathrm{m}$; specimens of different ages are not on the same scale. A-C. Juvenile Ancyrogondolella spp.; D. A. triangularis; E. A. inequalis; F. Mockina aff. matthewi; G. "Orchardella" mosheri morphotype B. Specimens A-C from the Dovško area (Slovenia), specimens D-F from the Buda Hills (Hungary) and specimen $\mathrm{G}$ from the Csővár area (Hungary).

\subsection{Appearance of Secondary Carina}

The development of secondary posterior carina is a common feature in the posteriorly expanded Lacian species, such as A. rigoi and A. triangularis (Fig. 4; Orchard, 2018). Even the holotype of $A$. rigoi bears this character (fig. 6.4 in Noyan and Kozur, 2007; see fig. 8.4 in Noyan and Vrielynck, 2000 for better quality of the same image). In some cases it may also occur among specimens with nearly parallel platform margins. The secondary carina always starts from the denticle posterior to the cusp and not directly from the cusp. This morphological character appears in quite a large variation. The secondary carina may generally consist of denticles in the number of one to three, but rarely four or even five denticles may develop. In some specimens, it is represented by a low ridge instead of separate denticles. It may evolve towards one or both posterolateral corners of the platform. Quite strange is that the development of the posterior carina does not show an evolutionary trend since almost all varieties appear at the same time around the middle of the Lacian 1, only the extreme forms with five carinal denticles are restricted to the higher Lacian 3 and lower Alaunian 1.

This morphology inspired Budurov (1972) to establish the genus Ancyrogondolella and the importance of this character was emphasized in the emended diagnosis of the genus given by Budurov and Sudar (1990).

\subsection{Remarks on the Genera Ancyrogondolella and Epi- gondolella}

The diagnosis of the genus Epigondolella given by Mosher (1968) was based mainly on the chosen type species, E. abneptis, the description of which (Huckriede, 1958, p. 156-157) is ambiguous involving conodonts with a large morphological variety. The problem is made even more complicated due to the uncertain age of the holotype of E. abneptis, which was recovered from a fissure-fill containing mixed assemblages of upper Lacian and Alaunian ammonoids (Orchard, 2018). The genus Ancyrogondolella was introduced by Budurov (1972) and later emended by Budurov and Sudar (1990) for conodonts that have a triangular, asymmetrical platform with strong denticulation all over the platform margins, a bifurcated keel and a bifurcated posterior carina. The only species the authors assigned to the genus was A. triangularis, however, such a restriction seems irrational. Recently Orchard (2018), contrary to his previous concept (e.g., Orchard, 2014, 2006, 1991a, b, 1983), assigned most of the Lacian species having a bifurcated keel to the genus Ancyrogondolella, and restricted the genus name Epigondolella for certain Norian species with a non-bifurcated keel. This decision was based on two arguments: (1) the supposed Alaunian age of the holotype of E. abneptis as discussed by Moix et al. (2007); (2) the fact that the occurrence of species with bifurcated keel in the Alaunian of North America is highly questionable (Orchard, 2018). In the Tethys, however, species characterized by a bifid keel do range up into the Middle Norian (Karádi et al., 2021; Karádi, 2018; Channell et al., 2003). Since the holotype of E. abneptis was chosen from the Tethyan succession of Sommeraukogel, it cannot be excluded that it has a bifurcated keel based only on its age.

Unfortunately the holotype of E. abneptis was lost and the original illustration is inadequate, not allowing the complete solution of the problem. However, some characters are visible that were omitted previously, and are probably worth considering. Firstly, the length of the free blade, which is between $1 / 2$ and $1 / 3$ unit length, but is closer to $1 / 3$. Secondly, the arched lower profile with the evident downward bending of the posterior platform. Both features are typical of the Lacian-type epigondolellids having a bifurcated keel, and become less common among taxa that 


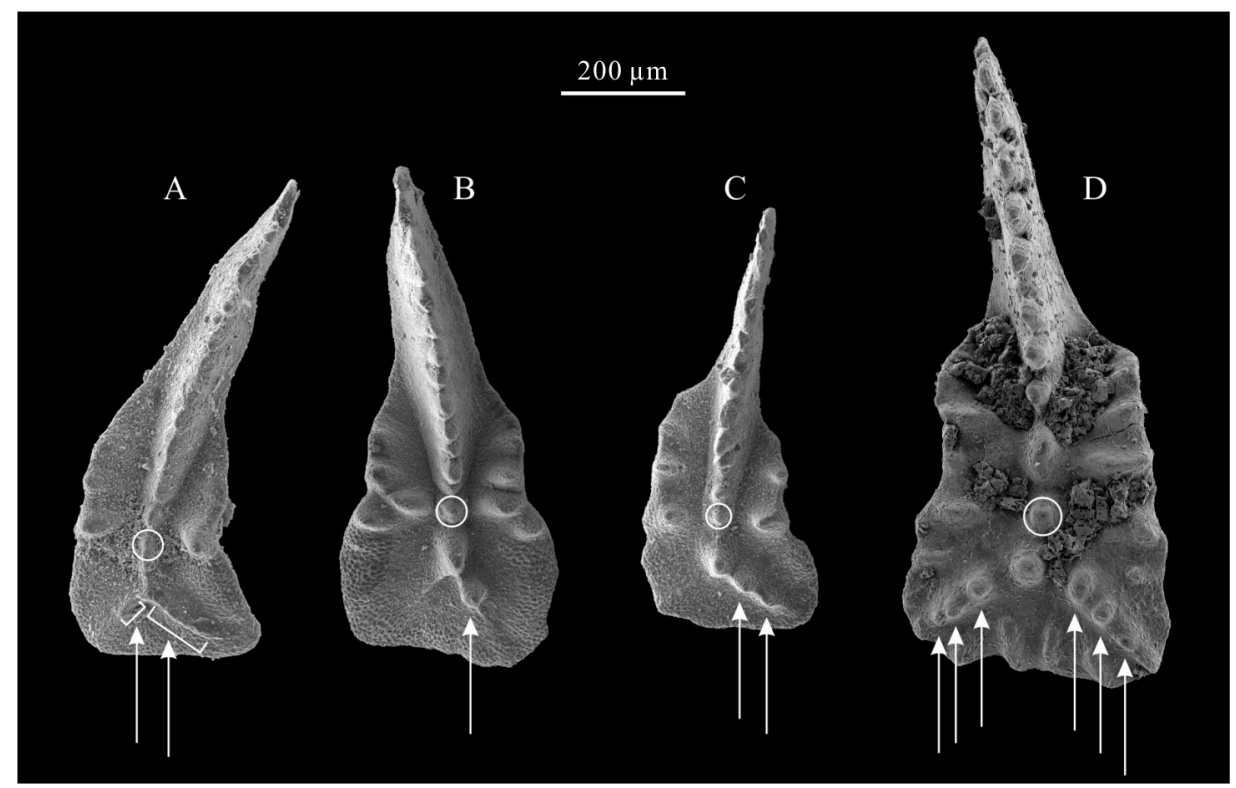

Figure 4. Examples for the variety of the secondary posterior carina in genus Ancyrogondolella. White arrows point to the denticles in the posterior carina developed behind the first denticle following the cusp. Cusp is marked with open circle. A. Specimen with low ridges towards both postero-lateral corners of the platform; B. specimen with one denticle towards the external postero-lateral corner; C. specimen with two partly fused denticles towards the internal posterolateral corner; D. specimen with three denticles towards both postero-lateral corners. All the specimens are on the same scale. See text for details. A-C. Ancyrogondolella ex. gr. rigoi; D. A. triangularis. Specimen A from the Csővár area (Hungary), specimens B and C from the Dovško area (Slovenia) and specimen D from the Buda Hills (Hungary).

originated in the Lacian-Alaunian transition or after. The position of the cusp and therefore the number of denticles in the posterior carina of the holotype of E. abneptis is less clear due to the quality and size of the original illustration. Two alternatives are possible.

(1) If the cusp is situated behind the line of the denticles of the anterior platform margins, it is followed only by one carinal denticle (Fig. 5A). In this case, the pit must be in the central position and the keel is most likely bifurcated. This would make the holotype of E. abneptis identical with Ancyrogondolella quadrata, the possibility of which cannot be ruled out due to the long range of the Lacian-type ancyrogondolellids in the Tethys, as mentioned before. In this case, the latter of the species would be a junior synonym of the former, and Ancyrogondolella would be a junior synonym of Epigondolella.

(2) If the cusp is located between the denticles of the anterior platform margins, the posterior carina is composed of two denticles (Fig. 5B). This character appears in the LacianAlaunian transitional interval, and is in correspondence with the forward shifting of the pit and the posterior prolongation of the keel, which is most likely single-lobed.

Moix et al. (2007) illustrated two specimens from the upper Alaunian beds of the Mersin mélange as Epigondolella abneptis sensu stricto. For a better understanding of the possibility of the two alternatives, these two specimens were re-examined and are re-figured herein. The first one (Fig. 5C) has two carinal denticles behind the cusp, a stepped lower profile, a forward shifted pit and a prolonged keel still showing a bifurcated termination. This specimen differs from the holotype of E. abneptis in its stepped lower margin, which suggests that it belongs to a separate species. The second specimen (Fig. 5D) has two denticles in the posterior carina, the second one of which is only a small and low one. Its lower profile is arched, which makes it very similar to the holotype. The pit is forward shifted and the keel is prolonged also in this specimen, but the keel end is squared. This specimen reveals that conodonts with an arched lower margin might bear a bifid keel (e.g., in $A$. quadrata) as well as a single-lobed keel, thus it is impossible to realize which character state was present in the holotype of $E$. abneptis. Since the exact age and important characters of the holotype of E. abneptis are unknown and no way of recovering the missing information seems to be possible anymore, it would be reasonable to solve this taxonomic problem from the practical view. In order to avoid major revisions of Norian conodont taxonomy and nomenclature, it would be wise to choose a replacement type species for genus Epigondolella. With this move the usage of the name Ancyrogondolella could be extended for the Norian taxa with a strongly bifurcated keel and Epigondolella could be restricted to species with a non-bifid one, as already applied by Orchard (2018).

\subsection{Comparison of the Western Tethys and the Eastern Pacific}

Comparing the Norian assemblages of different regions of the world is still a difficult task, because the availability of data is uneven both in time and in space. Considerable is the present knowledge on Lacian faunas from the western Tethys and the eastern Pacific, whereas detailed documentation of Alaunian and Sevatian assemblages is far more advanced in the latter region. The comparison of the Carnian-Norian boundary (CNB) interval and the earliest Norian is hampered by the different taxonomic concepts of the Tethyan and North American conodont specialists, which reached its peak after Orchard published the monograph about the conodonts from the CNB interval of 


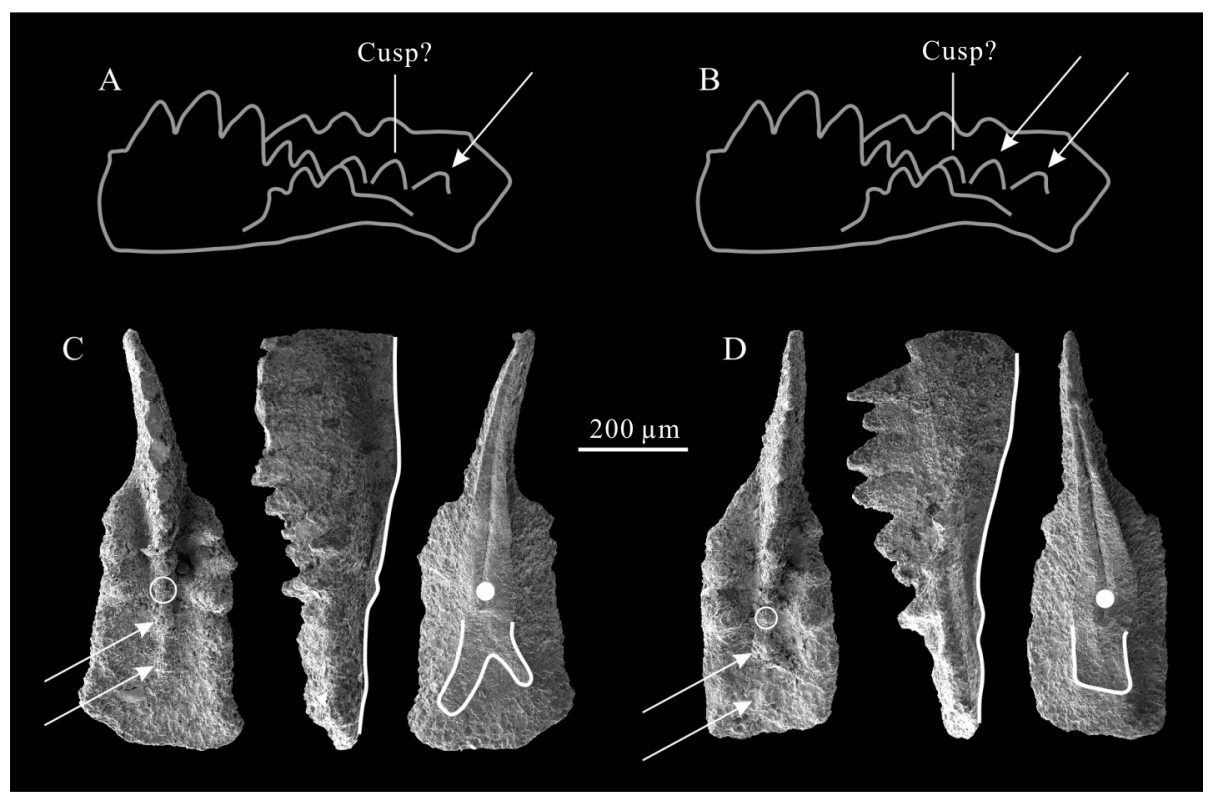

Figure 5. Sketches of the holotype of Epigondolella abneptis redrawn from Huckriede (1958, pl. 14, fig. 16) showing two alternatives for the length of the posterior carina (A and B), and specimens from the Mersin mélange, Turkey originally illustrated by Moix et al. (2007) as Epigondolella abneptis (C and D). White arrows point to the denticles in the posterior carina. Cusp is marked with open circle, pit with solid circle. White contours show the lower profile and the shape of the keel termination of the elements. A. The posterior carina is composed of one denticle; B. the posterior carina is composed of two denticles; C. specimen from Moix et al. (2007, pl. 1, fig. 1); D. specimen from Moix et al. (2007, pl. 1, fig. 2). Scale bar=200 $\mu$ m appling only for specimens C and D, which are on the same scale. See text for details.

Black Bear Ridge (Orchard, 2014). The 71 new species and 47 morphotypes established therein may suggest that the fauna of the CNB interval in the eastern Pacific is more diverse than that in the western Tethys. Baumgartner et al. (2018) stated the recovery of "a diverse conodont fauna from the latest Carnian conodont radiation zone sensu Orchard" from the Apuseni Mountains (Romania), but only Metapolygnathus parvus was mentioned by name and no further details were given about the faunal composition. The documentation of such fauna from the Tethys might improve the biostratigraphic correlation between the Tethyan Realm and North America. Nevertheless, the faunal turnover characterized by the mass occurrence of the Metapolygnathus communisti group (T2 in Mazza et al., 2018) is detectable both in the western Tethys and in the eastern Pacific. Endemic taxa were present in both regions in the early Lacian, although to some extent this might also be caused by the distinct views in systematics (Mazza et al., 2018). At least, representatives of the genus Acuminatella seem to be absent in the western Tethys. Generally both areas show only minor changes during the Lacian, but an evident faunal turnover occurred in the Lacian-Alaunian transitional interval (Karádi et al., 2021; Karádi, 2018; Orchard, 2018). In the western Tethys a coeval turnover was observed also among ammonoids (Krystyn, 2003), and evident difference is documented between the faunal composition of Carnian-Lower Norian and Upper Norian-Rhaetian corals (Roniewicz, 2011). In the eastern Pacific, this change in the conodont assemblages seems to be characterized not only by the origination of new taxa, but also by the disappearance of the typical Lacian species, unlike in the western Tethys, where the majority of the Lacian taxa cross this interval and range up into the lower Alaunian. From the Alaunian on a gradual reduction can be observed in certain parameters of the $\mathrm{P} 1$ conodont elements; at first in the overall width of the platform, soon followed by the decrease in length, too. This resulted in the development of smaller and narrower conodonts with respect to the Lacian taxa and led, as the final step, to the appearance of ancestral morphs represented by the genera Parvigondolella and Misikella (Karádi et al., 2019).

It is interesting to note that P1 conodont elements of the eastern Pacific seem to be more slender than their Tethyan equivalents, probably due to some kind of paleoecological reason. This raises the question whether the length : width ratio and the number of denticles in the posterior carina are relevant characters in the separation of taxa. Geometric morphometric analysis might be a useful tool for investigating this issue in the future. The above-mentioned difference may be in correspondence with the absence of extreme morphotypes in the Tethys, such as the narrow species assigned to genus Acuminatella in the Carnian-Norian boundary interval or Orchardella multidentata in the Alaunian. Orchard (2018) mentioned that $O$. elongata may occur outside the eastern Pacific, and O. mosheri is surely present in the Tethys. However, Tethyan specimens of $O$. mosheri morphotype A have only five denticles behind the cusp (e.g., Krystyn et al., 2007), which is the minimum criterion in this species. Specimens with longer posterior carina, so common in North America, are so far unknown in the Tethys, not to mention $O$. mosheri morphotype $\mathrm{C}$, which is certainly a North American endemic.

Although Norian conodonts are published from the eastern Tethys as well, illustrations from three views remain scarce (e.g., Du et al., 2020), hence involving this region in a comparative study is not yet well supported. Likewise, a more detailed comparison of the different regions based on their conodont faunas and performing paleobiogeographic evaluations 
will only be reasonable after the taxonomic revision of the Alaunian and Sevatian assemblages of the Tethys.

\section{CONCLUSIONS}

The overview of a large conodont material from Hungary and Slovenia and figured specimens from Sicily and the Americas allow an insight into the evolutionary trends of the Ancyrogondolella lineage during the Norian. The forward shifting of the pit, the posterior prolongation of the keel and the development of additional denticles in the posterior carina are strongly connected morphological changes, even if they were only partly and separately discussed by previous authors. This trend represents the repetition of the evolutionary steps, which occurred between the species Paragondolella noah and Metapolygnathus communisti in the Carnian. Besides the main trend, a decrease in the length of the free blade and an increase in the height of the anterior platform denticles can be observed.

All of these significant morphological alterations initiated in the Lacian-Alaunian transition, after a more or less steady phase that characterized the Lacian. This faunal turnover marks the beginning of the gradual decrease in overall width and length of platform conodonts that led to the development of ancestral morphs by the latest Norian. Quasi-coeval turnovers occurred among other groups, such as ammonoids and corals, and these faunal changes seem to coincide with disturbances in sedimentation (slump structures, sedimentary breccias) in the Tethys. It is not yet explored though, whether a connection exists between these phenomena.

The presence of a secondary carina is characteristic through the Lacian 2 to Alaunian 1 in certain species, however its development lacks any evolutionary trends. Contrary to early assumptions, it has no importance on the generic level, and its possible role in species differentiation is also questionable. The contour of the lower margin of platform elements shows an abrupt change around the Lacian-Alaunian transition. Adults of the Lacian dominantly have an arched profile, whereas that of the Alaunian and Sevatian specimens is mainly stepped or straight.

The evolutionary trends and the morphological variations listed above have key importance in the taxonomic and phylogenetic interpretations of the taxa belonging to the Ancyrogondolella lineage, on which the Norian biostratigraphy is mostly based. The fine subdivision of the Norian is truly required in order to avoid further misinterpretations caused by the lack of biostratigraphic control. Thorough study and description of the Tethyan assemblages will also enable detailed paleobiogeographical evaluations, which are not possible at the present state.

\section{ACKNOWLEDGMENTS}

Funding for this research was provided through the NKFIH PD-131536 Project and the Hantken Miksa Foundation. Open Access funding enabled and organized by Projekt DEAL. The constructive comments provided by the reviewers Tea Kolar-Jurkovšek and Martyn Golding improved the manuscript. Special thanks are given to Krisztina Buczkó (Department of Botany of the Hungarian Natural History Museum) and to Péter Szabó (University of Pécs) for their assistance in SEM imaging. The final publication is available at Springer via https://doi.org/10.1007/s12583-020-1381-z.
Open Access This article is distributed under the terms of the Creative Commons Attribution 4.0 International License (http://creativecommons.org/licenses/by/4.0/), which permits unrestricted use, distribution, and reproduction in any medium, provided you give appropriate credit to the original author and the source, provide a link to the Creative Commons license, and indicate if changes were made.

\section{REFERENCES CITED}

Baumgartner, N., Gawlick, H.-J., Missoni, S., et al., 2018. Open Marine Carnian Succession from the Apuseni Mountains (Codru-Moma Nappe System, Romania). In: Neubauer, F., Brendel, U., Friedl, G., eds., Advances of Geology in Southeast European Mountain Belts. XXI International Congress of the Carpathian Balkan Geological Association (CBGA). Sept. 10-13, 2018, Salzburg, Austria. Geologica Balcanica. 69

Budurov, K., 1972. Ancyrogondolella triangularis gen. et sp. n. (Conodonta) Mitteilungen der Gesellschaft der Geologie-und Bergbaustudenten, 21: $853-860$

Budurov, K. J., Sudar, M. N., 1990. Late Triassic Conodont Stratigraphy. In: Ziegler, W., ed., 1st International Senckenberg Conference and 5th European Conodont Symposium (ECOS V) Contributions VI-Papers on Conodonts and Ordovician to Triassic Conodont Stratigraphy. Courier Forschungsinstitut Senckenberg, 118: 203-240

Channell, J. E. T., Kozur, H. W., Sievers, T., et al., 2003. Carnian-Norian Biomagnetostratigraphy at Silická Brezová (Slovakia): Correlation to Other Tethyan Sections and to the Newark Basin. Palaeogeography, Palaeoclimatology, Palaeoecology, 191(2): 65-109. https://doi.org/10.1016/s0031-0182(02)006545

Diakow, L., Orchard, M. J., Friedman, R., 2011. Absolute Ages for the Norian Stage: A Contribution from Southern British Columbia, Canada. In: Haggart, J. W., Smith, P. L., eds., Proceedings of the 21st Canadian Paleontology Conference. Canadian Paleontology Conference Proceedings, 9: 27-28

Diakow, L., Orchard, M. J., Friedman, R., 2012. Absolute Ages for the Norian Stage: A Further Contribution from Southern British Columbia, Canada. Cordilleran Tectonics Workshop. Geological Association of Canada, Pacific Section, 2

Du, Y. X., Bertinelli, A., Jin, X., et al., 2020. Integrated Conodont and Radiolarian Biostratigraphy of the Upper Norian in Baoshan Block, Southwestern China. Lethaia, 53: 533-545. https://doi.org/10.1111/let.12374

Furin, S., Preto, N., Rigo, M., et al., 2006. High-Precision U-Pb Zircon Age from the Triassic of Italy: Implications for the Triassic Time Scale and the Carnian Origin of Calcareous Nannoplankton and Dinosaurs. Geology, 34: 1009-1012. https://doi.org/10.1130/g22967a.1

Galbrun, B., Boulila, S., Krystyn, L., et al., 2020. "Short" or "Long” Rhaetian? Astronomical Calibration of Austrian Key Sections. Global and Planetary Change, 192: 103253. https://doi.org/10.1016/j.gloplacha.2020.103253

Gehrels, G. E., Saleeby, J. B., Berg, H. C., 1987. Geology of Annette, Gravina, and Duke Islands, Southeastern Alaska. Canadian Journal of Earth Sciences, 24: 866-881

Guenser, P., Souquet, L., Dolédec, S., et al., 2019. Deciphering the Roles of Environment and Development in the Evolution of a Late Triassic Assemblage of Conodont Elements. Paleobiology, 45(3): 440-457. https://doi.org/10.1017/pab.2019.14

Huckriede, R., 1958. Die Conodonten der Mediterranen Trias und ihr Stratigraphischer Wert. Paläontologische Zeitschrift, 32(3): 141-175

Karádi, V., 2018. Middle Norian Conodonts from the Buda Hills, Hungary: An Exceptional Record from the Western Tethys. Journal of Iberian Geology, 44: 155-174. https://doi.org/10.1007/s41513-017-0009-3

Karádi, V., Kozur, H. W., Görög, Á., 2013. Stratigraphically Important Lower 
Norian Conodonts from the Csővár Borehole (Csv-1), HungaryComparison with the Conodont Succession of the Norian GSSP Candidate Pizzo Mondello (Sicily, Italy). In: Tanner, L. H., Spielmann, J. A., Lucas, S. G., eds., The Triassic System. New Mexico Museum of Natural History and Science Bulletin, 61: 284-295

Karádi, V., Pelikán, P., Haas, J., 2016. Conodont Biostratigraphy of Upper Triassic Dolomites of the Buda Hills (Transdanubian Range, Hungary). Bulletin of the Hungarian Geological Society, 146(4): 371-386 (in Hungarian with English Abstract)

Karádi, V., Kolar-Jurkovšek, T., Jurkovšek, B., 2019. The Lower/Middle Norian (Upper Triassic) Transition: Conodonts of the Dovško Succession, Slovenia. 3rd International Congress on Stratigraphy, July 2-5, 2019, Milano, Italy. Abstract Book. Società Geologica Italiana. 53. https://doi.org/10.3301/absgi.2019.04

Karádi, V., Virág, A., Kolar-Jurkovšek, T., et al., 2020. Stress-Related Evolution in Triassic Conodonts and the Middle Norian Juvenile Mortality. In: Guex, J., Torday, J. S., Miller, W. B. Jr., eds., Morphogenesis, Environmental Stress and Reverse Evolution. Springer, Cham. 37-58. https://doi.org/10.1007/978-3-030-47279-5_4

Karádi, V., Kolar-Jurkovšek, T., Gale, L., et al., 2021. New Advances in Biostratigraphy of the Lower/Middle Norian Transition: Conodonts of the Dovško Section, Slovenia. Journal of Earth Science, 32(3): 677-699. https://doi.org/10.1007/s12583-020-1382-y

Kent, D. V., Olsen, P. E., Muttoni, G., 2017. Astrochronostratigraphic Polarity Time Scale (APTS) for the Late Triassic and Early Jurassic from Continental Sediments and Correlation with Standard Marine Stages. Earth-Science Reviews, 166: 153-180. https://doi.org/10.1016/j.earscirev.2016.12.014

Krystyn, L., 2003. Upper Triassic Substage Boundaries and Their Ammonoid Record: Divided between Gradation, Faunal Turnover and Extinction. Joint Annual Meeting GAC-MAC-SEG, Vancouver

Krystyn, L., Richoz, S., Gallet, Y., et al., 2007. Updated Bio- and Magnetostratigraphy from Steinbergkogel (Austria), Candidate GSSP for the Base of the Rhaetian Stage. Albertiana, 36: 164-173

Maron, M., Rigo, M., Bertinelli, A., et al., 2015. Magnetostratigraphy, Biostratigraphy, and Chemostratigraphy of the Pignola-Abriola Section: New Constraints for the Norian-Rhaetian Boundary. Geological Society of America Bulletin, 127(7/8): 962-974. https://doi.org/10.1130/b31106.1

Mazza, M., Rigo, M., Nicora, A., 2011. A New Metapolygnathus Platform Conodont Species and Its Implications for Upper Carnian Global Correlation. Acta Palaeontologica Polonica, 56(1): 121-131. https://doi.org/10.4202/app.2009.1104

Mazza, M., Rigo, M., Gullo, M., 2012a. Taxonomy and Biostratigraphic Record of the Upper Triassic Conodonts of the Pizzo Mondello Section (Western Sicily, Italy), GSSP Candidate for the Base of the Norian. Rivista Italiana di Paleontologia e Stratigrafia, 118(1): 85-130. https://doi.org/10.13130/2039-4942/5993

Mazza, M., Cau, A., Rigo, M., 2012b. Application of Numerical Cladistics Analyses to the Carnian-Norian Conodonts: New Approach for Phylogenetic Interpretations. Journal of Systematic Palaeontology, 10(3): 401-422. https://doi.org/10.1080/14772019.2011.573584

Mazza, M., Nicora, A., Rigo, M., 2018. Metapolygnathus parvus Kozur, 1972 (Conodonta): A Potential Primary Marker for the Norian GSSP (Upper
Triassic). Bollettino della Società Paleontologica Italiana, 57(2): 81-101

Moix, P., Kozur, H. W., Stampfli, G. M., et al., 2007. New Paleontological, Biostratigraphic and Paleogeographic Results from the Triassic of the Mersin Mélange, SE Turkey. New Mexico Museum of Natural History and Science Bulletin, 41: 282-311

Mosher, L. C., 1968. Triassic Conodonts from Western North America and Europe and Their Correlation. Journal of Paleontology, 42(4): 895-946

Noyan, Ö., Kozur, H., 2007. Revision of the Late Carnian-Early Norian Conodonts from the Stefanion Section (Argolis, Greece) and Their Paleobiogeographic Implications. Neues Jahrbuch für Geologie und Paläontologie Abhandlungen, 245(2): 159-178. https://doi.org/10.1127/0077-7749/2007/0245-0159

Noyan, Ö. F., Vrielynck, B., 2000. Importance of Morphogenetic Analysis in Taxonomy: An Example from Triassic Platform Conodonts. Neues Jahrbuch für Geologie und Paläontologie-Monatshefte, 10(11): 577-594

Ogg, J. G., 2012. Triassic. In: Gradstein, F. M., Ogg, J. G., Schmitz, M. D., et al., eds., The Geological Time Scale. Elsevier, Amsterdam. 681-730

Orchard, M. J., 1983. Epigondolella Populations and Their Phylogeny and Zonation in the Upper Triassic. Fossils and Strata, 15: 177-192

Orchard, M. J., 1991a. Late Triassic Conodont Biochronology and Biostratigraphy of the Kunga Group, Queen Charlotte Islands, British Columbia. Geological Survey of Canada Paper, 90-10: 173-193

Orchard, M. J., 1991b. Upper Triassic Conodont Biochronology and New Index Species from the Canadian Cordillera. In: Orchard, M. J., McCracken, A. D., eds., Ordovician to Triassic Conodont Paleontology of the Canadian Cordillera. Geological Survey of Canada Bulletin, 417: 299-335

Orchard, M. J., 1994. Late Triassic (Norian) Conodonts from Peru. Palaeontographica Abteilung A, 233(1-6): 203-208

Orchard, M. J., 2006. Late Paleozoic and Triassic Conodont Faunas of Yukon and Northern British Columbia and Implications for the Evolution of the Yukon-Tanana Terrane. In: Colpron, M., Nelson, J. L., eds., Paleozoic Evolution and Metallogeny of Pericratonic Terranes at the Ancient Pacific Margin of North America, Canadian and Alaskan Cordillera. Geological Association of Canada Special Paper, 45: 229-260

Orchard, M. J., 2014. Conodonts from the Carnian-Norian Boundary (Upper Triassic) of Black Bear Ridge. New Mexico Museum of Natural History and Science Bulletin, 64: 1-139

Orchard, M. J., 2018. The Lower-Middle Norian (Upper Triassic) Boundary: New Conodont Taxa and a Refined Biozonation. In: Over, D. J., Henderson, C. M., eds., Conodont Studies Dedicated to the Careers and Contributions of Anita Harris, Glen Merrill, Carl Rexroad, Walter Sweet, and Bruce Wardlaw. Bulletins of American Paleontology, 395/396: 165-193

Rigo, M., Mazza, M., Karádi, V., et al., 2018. New Upper Triassic Conodont Biozonation of the Tethyan Realm. In: Tanner, L. H., ed., The Late Triassic World: Earth in a Time of Transition. Topics in Geobiology, 46: 189-235. https://doi.org/10.1007/978-3-319-68009-5_6

Roniewicz, E., 2011. Early Norian (Triassic) Corals from the Northern Calcareous Alps, Austria, and the Intra-Norian Faunal Turnover. Acta Palaeontologica Polonica, 56(2): 401-428. https://doi.org/10.4202/app.2009.0092

Wotzlaw, J.-F., Guex, J., Bartolini, A., et al., 2014. Towards Accurate Numerical Calibration of the Late Triassic: High-Precision U-Pb Geochronology Constraints on the Duration of the Rhaetian. Geology, 42(7): 571-574. https://doi.org/10.1130/g35612.1 